\title{
Preparación de chocolate en metate
}

Metate chocolate preparation

\author{
Blanca Azalia López Hernández a , Juan Francisco Gutiérrez Rodríguez b , Juan Ramírez \\ Godinez ${ }^{\mathrm{c}}$
}

\begin{abstract}
:
Since pre-hispanic times, chocolate has a preponderant value at the table of those who consume it, this drink made from ground cocoa in the metate, with a bitter and spicy taste that delighted the great Aztec lords, is an important part of the Mexican history and rejoices to be one of the most appreciated and versatile preparations in the palates around the world.
\end{abstract}

Keywords:

Aztecs, metate, cocoa

\section{Resumen:}

Desde la época prehispánica, el chocolate tiene un valor preponderante en la mesa de quien lo consume, esta bebida hecha a base de cacao molido en el metate, con un gusto amargo y picante que deleitaba a los grandes señores aztecas, forma parte importante en la historia de México y se regocija de ser uno de las preparaciones más apreciadas y versátiles en los paladares de todo el mundo.

\section{Palabras Clave:}

Aztecas, metate, cacao

\section{Introducción}

Del náhuatl "cacahuatl" que significa jugo amargo, el cacao es parte fundamental en la historia, cultura y economía de México desde la época prehispánica, se sabe que tiene sus orígenes en Sudamérica, sin embargo, es en Mesoamérica donde comienza a domesticarse, teniendo los primeros vestigios de su uso en el cerro del Manatí en Veracruz.

Culturalmente, denominado "Theobroma cacao" o alimento de los dioses, era muy apreciado como reconstituyente y estimulante; simbolizaba también la abundancia, gobernabilidad y ascendencia.

Las mujeres molían el cacao de rodillas frente al metate con la ayuda del metlapilli (hijo del metate) ambos elaborados de piedra volcánica, preparaban una masa amarga que era recibida en la bandeja de manera llamada texpetate, para después convertirlo en la bebida fortificante tan apreciada por los aztecas y en particular para el tlatoani Moctezuma.

Estas semillas eran utilizadas como forma de cambio en el trueque y tributo para el tlatoani,

\footnotetext{
a Autor de Correspondencia, Universidad Autónoma del Estado de Hidalgo, Instituto de Ciencias Económico - Administrativas, gastronomía, Email: blanca.lopez@uaeh.edu.mx

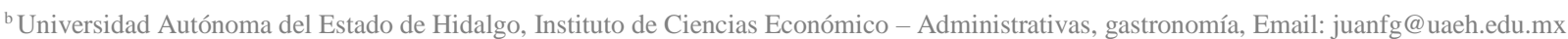

c Universidad Autónoma del Estado de Hidalgo, Instituto de Ciencias Económico - Administrativas, gastronomía, Email: juan_ramirez@uaeh.edu.mx
} 
costumbre llevada a cabo aun después de la conquista; y aunque es Cristóbal Colon el primero que lo lleva a España, es Hernán Cortes quien entiende su valor y lo presenta al emperador español Carlos V en 1528 con quien comienza su popularidad global.

Es en los conventos donde las monjas con influencia española y las esclavas africanas dan un giro radical a la tan apreciada bebida, que pasa de ser amarga y picante a tener un sabor dulce y aromático por la adición de azúcar y espacias, su gusto fue tanto que a algunos grupos religiosos se les prohibió su consumo en público y la orden de monjas concepcionistas tuvieron que firmar un voto de no tomar chocolate por las propiedades afrodisiacas que se le atribuían.

El consumo de este se extiende y su uso se generaliza en el México virreinal, se puede encontrar tanto en las mesas con mayores recursos como siendo parte de las meriendas de las clases trabajadoras.

Su popularidad fue tanta que en 1847 se empiezan a fabricar las barras de chocolate con los fabricantes ingleses, se crearon nuevos utensilios que facilitaran su elaboración desde el molino de mano hasta maquinas industriales que facilitan la torrefacción hasta el atemperado y moldeado, dejando el uso del metate a un lado.

En la actualidad la producción del cacao se ha extendido, en México figuran las regiones del Soconusco en Chiapas y el Chontal en Tabasco como productores del cacao criollo, en el caribe predomina el trinitario, pero son Costa de Marfil y Ganha en África quienes cuentan con la mayor producción a nivel mundial de la variedad forastero, en producción chocolatera son Suiza y Bélgica dos de los países con mayor reconocimiento.

Este ingrediente que se funde a la temperatura del cuerpo por su aceptación generalizada logro unir a todas las clases sociales, siendo hoy una de las mayores contribuciones de México para la gastronomía mundial.

\section{Desarrollo de la practica:}

1. Objetivo general de la practica:

Elaborar tablillas de chocolate de forma artesanal a partir de utensilios prehispánicos.

2. Instrumentos necesarios:

Metate, metlapilli, texpetate

3. Insumos requeridos:

\begin{tabular}{|l|l|}
\hline INGREDIENTES & CANTIDAD \\
\hline Cacao & $0.250 \mathrm{~kg}$ \\
\hline Azúcar morena & $0.100 \mathrm{~kg}$ \\
\hline Canela & $0.005 \mathrm{~kg}$ \\
\hline Almendras & $0.100 \mathrm{~kg}$ \\
\hline Vainilla & $0.005 \mathrm{~kg}$ \\
\hline
\end{tabular}

Tabla 1. Elaboración propia

Preparación:

1. Tostar y descascarillar el cacao

2. Pelar las almendras

3. Moler los granos en el metate con la ayuda del metlapilli.

4. Incorporar azúcar, almendras, canela y vainilla paulatinamente.

5. Moler hasta obtener una pasta moldeable.

6. Formar las tablillas de chocolate.

\section{Conclusiones}

Se concluye que se pueden realizar tablillas de chocolate utilizando utensilios de origen prehispánicos con características similares a los elaborados de forma industrial.

\section{Referencias}

[1] Adame, M. (2012). Elementos generales del sistema alimentario en el México Colonial. En M.A. Adame. (Ed.), Alimentación en México ensayos de Antropología e Historia (pp. 103-134). México: Navarra.

[2] Flores, M. (productor) y Kuri, J. (2017). Cacao, historia usos y costumbres. (Video). En https://www.youtube.com/watch?v=-mwbXXR1sQ\&t=1s

[3] Ramos, M. (2012). La cocina conventual novohispana. En M. de Orellana (Ed.), Elogio de la cocina mexicana: patrimonio cultural de la humanidad (pp. 113-119). México: Artes de México y del mundo

[4] Velázquez, M.E. (2011). Comida, chocolate y otros brebajes: africanas y afrodescendientes en el México Virreinal. En C. Good \& L.E. Corona (Ed.), Comida, cultura y modernidad en México, perspectivas antropológicas e históricas (pp. 207-224). México: INAH - Conaculta. 